\title{
Biology and Management of Torpedograss (Panicum repens) in Ornamental Landscape Planting Beds ${ }^{1}$
}

\author{
Yuvraj Khamare, Candice Prince, and Chris Marble ${ }^{2}$
}

\section{Introduction}

Torpedograss (Panicum repens) is one of the most invasive perennial grass species in Florida landscapes. Torpedograss is currently listed as a noxious weed in Alabama, Arizona, Hawaii, and Texas and is ranked as a Category I invasive by the Florida Invasive Species Council (FISC), meaning that it alters native plant communities through its impacts (FISC 2019; PIER 2021; USDA-NRCS 2021). This document was written for green industry professionals and others to aid in the identification and management of torpedograss in landscape planting beds. For information on torpedograss management in turfgrass, see "Torpedograss Biology and Management in Turf."

\section{Species Description}

\section{Class}

Monocots

\section{Family}

Poaceae

\section{Other Common Names}

Creeping panic, panic rampant, couch panicum, wainaku grass, quack grass, dogtooth grass, and bullet grass

\section{Life Span}

Perennial (living two or more years)

\section{Habitat}

Torpedograss is commonly found in cultivated and abandoned fields, open ground, gardens, lawns, and landscape planting beds. It also flourishes in aquatic habitats like wet pastures, lakeshores, freshwater and brackish marshes, and other wetland areas (Prince and Macdonald 2020). It is found in more than $70 \%$ of Florida's public waters (Schardt 1994) and is considered one of the most troublesome grassy weeds in southern Florida due to its impacts on native plant communities (Tarver 1979).

\section{Distribution}

The native range of torpedograss is unknown, but it is thought to be native to the tropical and subtropical regions of Europe, Asia, and Africa (Hossain et al. 1999). According to Holm et al. (1977), it is native to Eurasia and has spread throughout the tropics and subtropics of both hemispheres. It is now widely spread throughout the world and is well established as one of the world's worst weeds (Holm et al. 1977; Panchal 1981). Torpedograss was introduced to the United States prior to 1876 , either in ship ballast or as a potential forage grass for southeastern states (Tabor 1952). It was widely distributed throughout Florida in the early 1900 s for cattle forage.

1. This document is ENH1351, one of a series of the Environmental Horticulture Department, UF/IFAS Extension. Original publication date December 2021. Visit the EDIS website at https://edis.ifas.ufl.edu for the currently supported version of this publication.

2. Yuvraj Khamare, graduate research assistant, Environmental Horticulture Department, UF/IFAS Mid-Florida Research and Education Center, Apopka, FL; Candice Prince, assistant professor, Agronomy Department, Center for Aquatic and Invasive Plants, Gainesville, FL; and Chris Marble, Environmental Horticulture Department, UF/IFAS Mid-Florida Research and Education Center, Apopka, FL; UF/IFAS Extension, Gainesville, FL 32611.

The Institute of Food and Agricultural Sciences (IFAS) is an Equal Opportunity Institution authorized to provide research, educational information and other services only to individuals and institutions that function with non-discrimination with respect to race, creed, color, religion, age, disability, sex, sexual orientation, marital status, national origin, political opinions or affiliations. For more information on obtaining other UF/IFAS Extension publications, contact your county's UF/IFAS Extension office. U.S. Department of Agriculture, UF/IFAS Extension Service, University of Florida, IFAS, Florida A \& M University Cooperative Extension Program, and Boards of County Commissioners Cooperating. Nick T. Place, dean for UF/IFAS Extension. 


\section{Growth Habit}

Torpedograss is a perennial grass that can grow up to 40 inches tall from creeping rhizomes (underground stems that form lateral shoots and roots) and stolons (aboveground stems that creep across the ground or float in aquatic environments).

\section{Seedling}

Torpedograss produces seeds with little to no viability. It primarily spreads vegetatively by rhizomes and stem fragments, which can form new plants. New buds are produced along the entire length of the rhizome, which form into aerial stems (Figure 1).

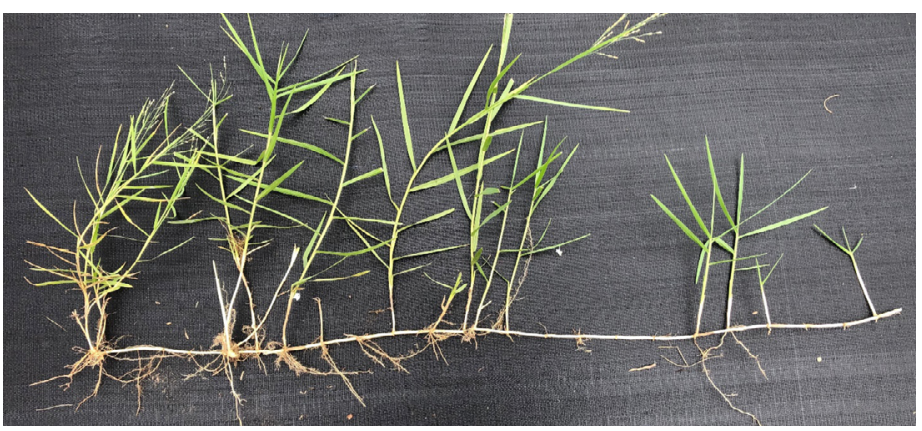

Figure 1. Torpedograss vegetative reproduction through rhizomes. Credits: Chris Marble, UF/IFAS

\section{Shoot}

Culms (aerial stems) are 15 to 40 inches in height, rigid, and erect, and they originate from sturdy, robust rhizomes that have many nodes. The stem's base is wrapped with bladeless overlapping sheaths. The leaf sheaths are hairy with thin and dry margins. The upper sheaths are mostly glabrous (lacking hairs) with hairs restricted to the upper margin. The ligules (a scale at the attachment of the leaf sheaf to the leaf blade) are a short-ciliate membrane surrounded by fringed hairs. The leaf blades are stiff, linear, flat, or folded with a waxy or whitish surface and about 10 inches long (Figure 2). The leaf blades are approximately 0.1 inch wide when flat and 0.2 inch wide folded. The leaves are stiff and rigid, flat, or rolled and spreading.

\section{Roots}

The name "torpedograss" originates from its rhizomes, which are rigid with sharp-pointed, torpedo-like growing tips (Figure 3). Torpedograss has both long and short knotty rhizomes. The rhizomes can grow up to 20 feet long and are 0.1 to 0.2 inch in diameter with overlapping brownish-to-white scales and swollen bulbil-like nodes. The bulbil-like nodes are known to have abundant carbohydrate reserves. These reserves are used by the plant for rapid regeneration from axillary buds when the rhizomes are divided or cut. Most of the rhizomes of torpedograss are present in the top 24 inches of soil.

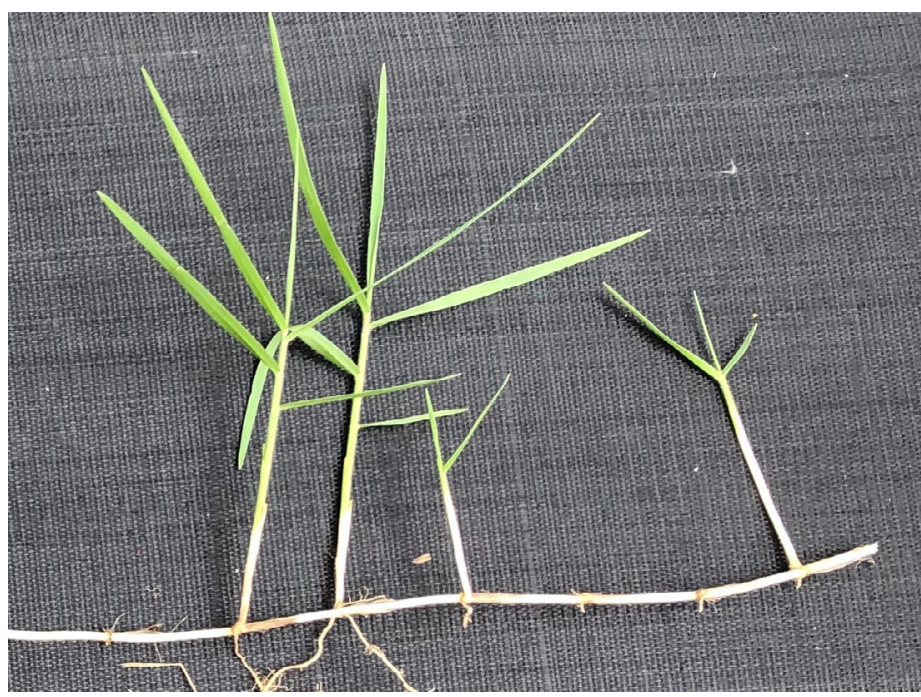

Figure 2. Torpedograss shoots. Credits: Chris Marble, UF/IFAS

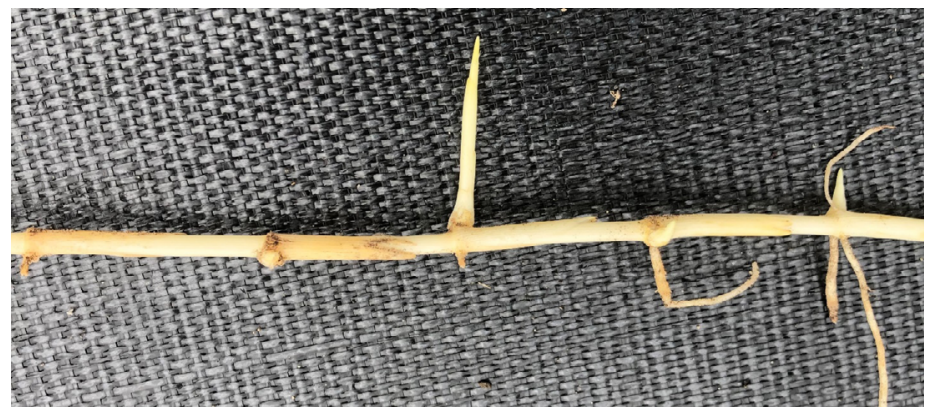

Figure 3. Sharp-pointed rhizome of torpedograss.

Credits: Chris Marble, UF/IFAS

\section{Inflorescence}

In Florida, torpedograss flowers throughout the summer and into early fall from May to November. The inflorescence or the flowering portion is a loose open panicle, 3 to 9 inches long with few to many branches (Figure 4). The stalked spikelets (flowering parts attached at their base to the spike) are ovate, glabrous, and approximately $2-3 \mathrm{~mm}$ long and $1 \mathrm{~mm}$ wide. The outermost spikelet bract (first glume) is short, truncate, and loose, and it nearly encircles the base of the other spikelet bracts.

\section{Fruit and Seeds}

The seeds are white, smooth, and 2.2-3.1 mm long. The fruits are lanceolate (lance-shaped) with straw-colored caryopses (dry fruit). The caryopsis is pale yellow and oval (Figure 5). 


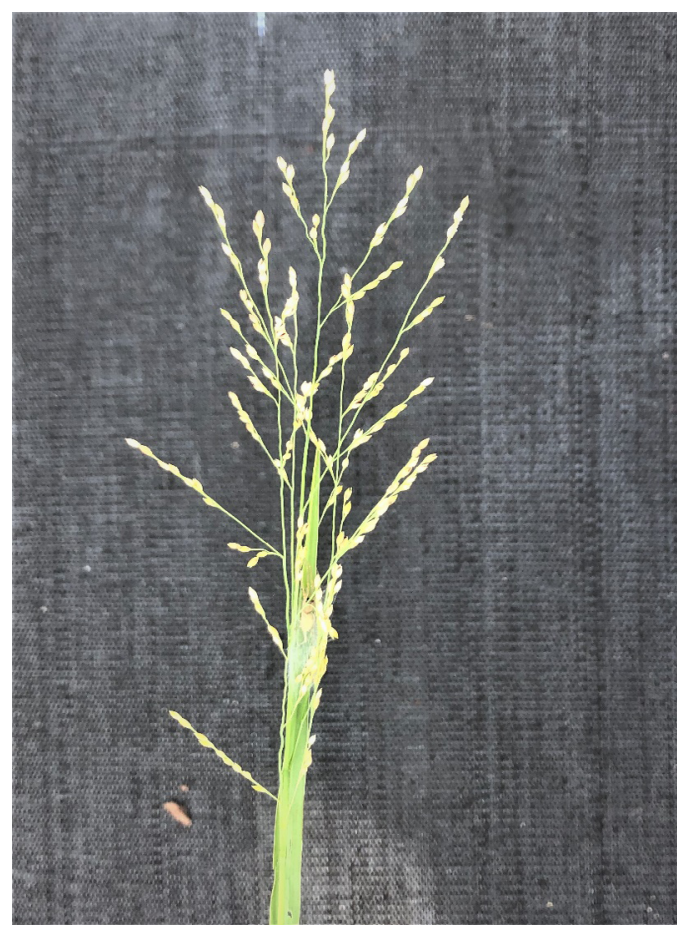

Figure 4. Torpedograss inflorescence.

Credits: Chris Marble, UF/IFAS

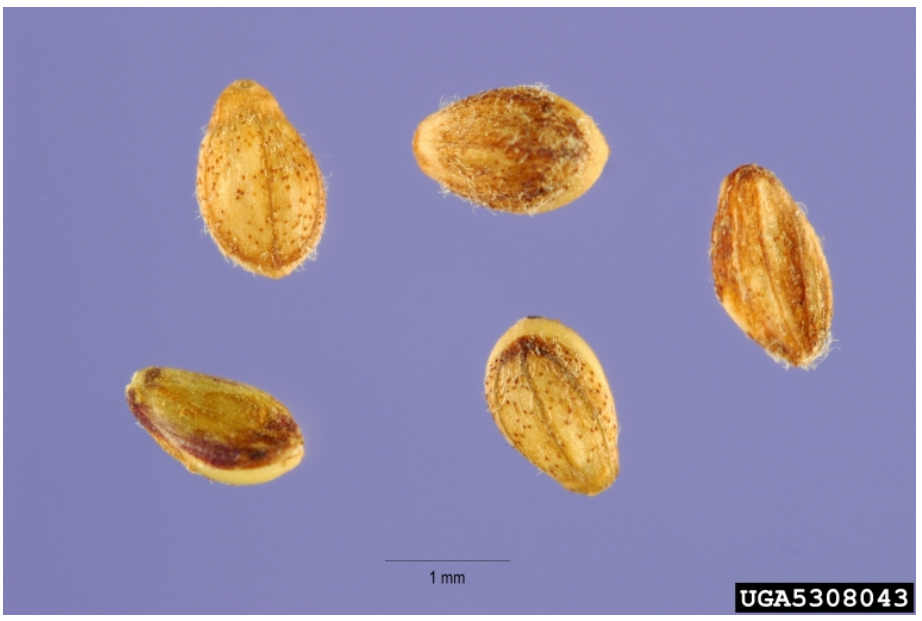

Figure 5. Torpedograss fruits.

Credits: Steve Hurst, USDA NRCS PLANTS Database, Bugwood.org

\section{Similar Species}

Torpedograss can be confused with a similar-looking grass called maidencane (Panicum hemitomon), which is native to Florida. Maidencane is a common grass of wetlands and prefers to grow in water or wet soils. Maidencane does not have torpedo-shaped rhizomes.

\section{Plant Biology}

Torpedograss prefers to grow in warm-to-hot climates in sandy soils with abundant moisture and full sun (Holm et al. 1977). Torpedograss grows in several soil types, from sandy, well-drained soils to heavy waterlogged soils, and it can tolerate a moderate range of salinity levels (Ramiti et al. 1979). It thrives on wet organic soil but can also grow on high land under drought conditions, and the rhizomes can survive extended periods of water stress (Hodges and Jones 1950). It is sensitive to prolonged cold temperature, limiting it from spreading at upper latitudes or altitudes. Torpedograss sprouting, shoot growth, height, and leaf area generally increase as the temperature increases (Hossain et al. 2001; Wilcut et al. 1988).

Torpedograss establishes and spreads vegetatively via rhizomes and stem fragmentation (Holm et al. 1977). Rhizome sprouting occurs via the axillary buds, which are produced along the entire length of the rhizomes (Wilcut et al. 1988). Up to $60 \%$ of initial fresh weight of rhizomes are tolerant to desiccation. The plant allocates much of its biomass to the rhizomes, which are strong enough to penetrate wood and asphalt. On a golf course in Florida, it was observed that $87 \%$ of total torpedograss biomass was present in its rhizomes (Busey 2003). Torpedograss regenerative buds are not limited to its rhizomes; they can also form on tillers and stem fragments.

There is limited information available regarding the seed production or viability of torpedograss. It has been reported that the seeds are largely nonviable. Researchers were unable to stimulate germination of seeds from torpedograss in the United States (Wilcut et al. 1988); however, limited production of viable seeds has been observed in Florida.

\section{Management \\ Prevention and Cultural Control}

Torpedograss can be extremely difficult and expensive to control. Prevention should be part of every management plan. For torpedograss, the spread of rhizomes can be limited by controlling populations near waterways, properly cleaning machinery such as lawnmowers and boats, and only accepting materials like soil, mulch, and hay from certified sources. In addition, maintaining a healthy ecosystem with native species diversity may limit the amount of open and disturbed habitat available for torpedograss establishment (Mack et al. 2000).

\section{Mechanical Control}

Mechanical control is only moderately effective for controlling torpedograss. Mechanical methods include tillage, digging, mowing and burning; however, these methods can result in numerous rhizome fragments that can sprout and produce aerial shoots. Hoeing and hand weeding are also known to be ineffective due to its rapid growth from underground rhizomes. Continuous tillage can be effective under the right conditions, such as soil conditions, climate, 
and the depth of tillage. In many natural areas, particularly wetlands, tillage is impractical and difficult to use. Digging the rhizomes out has been attempted in few studies, but in large areas it is impractical, expensive, and time-consuming, and it usually results in further spread of rhizome fragments (Chandrasena 1990; Manipura and Somaratne 1974). However, this method may work in very small areas, such as landscape beds where the infestation is confined. Mowing is only marginally effective, and torpedograss can tolerate grazing and trampling. Fire can be used to destroy the aboveground vegetation, but the rhizomes are protected underground and can resprout.

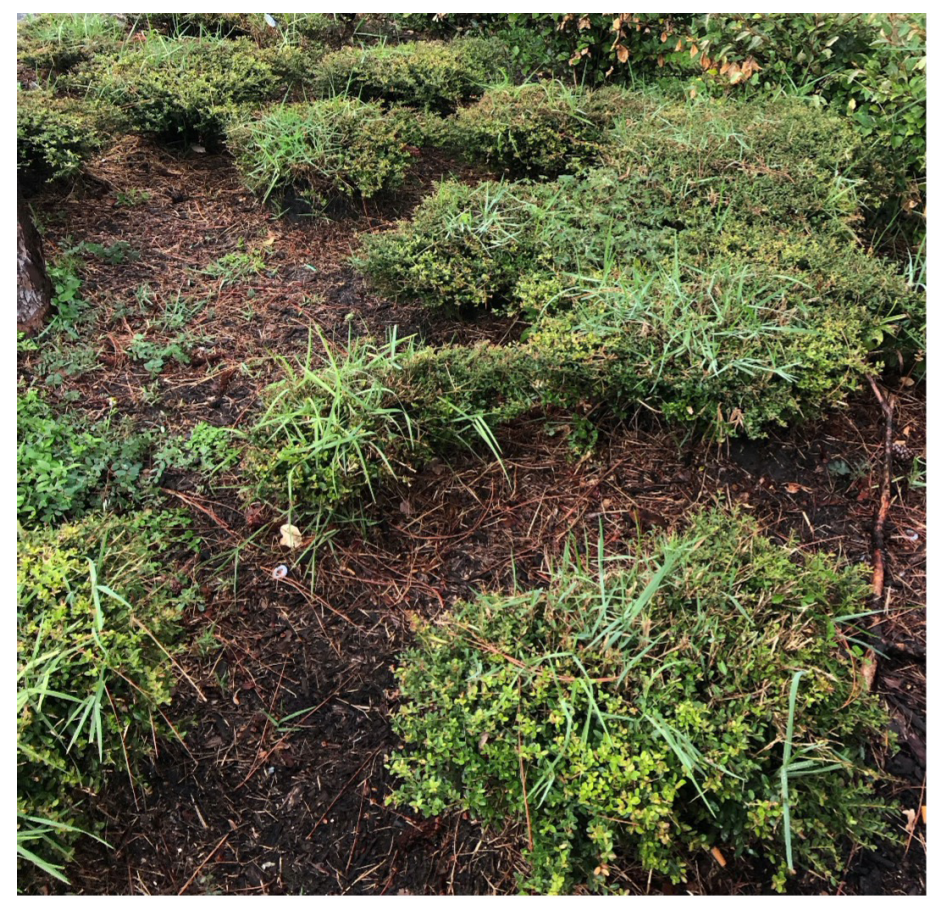

Figure 6. Torpedograss growing up through the canopy of dwarf yaupon holly shrubs. Glyphosate had been used in the area around the shrubs for postemergence control, but a selective option would be needed for control within the plant canopy.

Credits: Chris Marble, UF/IFAS

\section{Chemical Control}

Postemergence herbicides are the most common and widely used method of torpedograss control. Two of the most effective herbicides for torpedograss control are glyphosate and imazapyr (McCarty et al. 1993). While glyphosate can be used as in landscape planting beds if applied as a directed application, imazapyr is not labeled for use in landscapes and application can result in severe injury or death to landscape ornamentals. In areas where glyphosate can be applied without contacting nearby ornamental plants, it can be applied as a $2 \%$ to $3 \% \mathrm{v} / \mathrm{v}$ solution; however, repeated applications are often needed for complete control (Nir 1988). In cases where torpedograss is growing through the canopy of shrubs (Figure 6), graminicides such as fluazifop-P-butyl
(Fusilade II), which is labeled for torpedograss suppression, or sethoxydim (Segment II), can be applied as an overthe-top application to most broadleaf ornamental plants. However, these herbicides are typically less effective than glyphosate and multiple applications are usually needed for long-term control (Enloe et al. 2018). Because torpedograss primarily spreads via rhizomes, preemergence herbicides are not an effective option.

\section{References}

Busey, P. 2003. "Reduction of Torpedograss (Panicum repens) Canopy and Rhizomes by Quinclorac Split Applications." Weed Technology 17 (1): 190-194. https://doi. org/10.1614/0890-037X(2003)017[0190:ROTPRC]2.0.CO;2

Chandrasena, J. P. N. R. 1990. “Torpedograss (Panicum repens L.) Control with Lower Rates of Glyphosate." Tropical Pest Management 36 (4): 336-342. https://doi. org/10.1080/09670879009371505

Enloe, S. F., M. D. Netherland, and D. K. Lauer. 2018. "Evaluation of Sethoxydim for Torpedograss Control in Aquatic Wetland Sites." J. Aquat. Plant Manage. 56:93-100.

Florida Invasive Species Council (FISC). 2019. http://www. fleppc.org

Hodges, E. M., and D. W. Jones. 1950. “Torpedo Grass.” Ag. Experiment Station Circular S 14. Gainesville: University of Florida Institute of Food and Agricultural Sciences (IFAS).

Holm, L. G., D. L. Plocknett, J. V. Pancho, and J. P. Herberger. 1977. “The World's Worst Weeds: Distribution and Biology." Honolulu: University Press of Hawaii.

Hossain, M. A., H. Akamine, I. Nakamura, Y. Ishimine, and H. Kuramochi. 2001. "Influence of Temperature Levels and Planting Time on the Sprouting of Rhizome-Bud and Biomass Production of Torpedograss (Panicum repens L.) in Okinawa Island, Southern Japan." Weed Biology and Management 1 (3): 164-169. https://doi. org/10.1046/j.1445-6664.2001.00028.x

Hossain, M. A., Y. Ishimine, H. Akamine, S. Murayama, S. M. M. Uddin, and K. Kuniyoshi. 1999. "Effect of Burial Depth on Emergence of Panicum repens." Weed Science 47 (6): 651-656. https://doi.org/10.1017/S0043174500091281

Mack, R. N., D. Simberloff, W. M. Lonsdale, H. Evans, M. Clout, and F. A. Bazzaz. 2000. "Biotic Invasions: Causes, Epidemiology, Global Consequences, and Control.” 
Ecological Applications 10 (3): 689-710. https://doi. org/10.1890/1051-0761(2000)010[0689:BICEGC]2.0.CO;2

Manipura, W. V., and A. Somaratne. 1974. "Some Effects of Manual and Chemical Defoliation on the Growth and Carbohydrate Reserves of (Panicum repens L.)." Weed Res. 14 (3): 167-172. https://doi.org/10.1111/j.1365-3180.1974. tb01033.x

McCarty, L. B., J. M. Higgins., and D. L. Colvin. 1993. "Selective Torpedograss (Panicum repens) Control in Bermudagrass (Cynodon spp.) Turf." Weed Technol. 7:911-915. https://doi.org/10.1017/S0890037X00037982

Nir, A. 1988. "Combined Control of Both Weeds and Mosquitoes in Drainage Canals." Phytoparasitica 16 (4): 385-386.

Panchal, Y. C. 1981. "Control of Panicum repens L. in Field Channels." Proc. 8th Asian Pacific Weed Sci. Conf., 281-286.

Pacific Islands Ecosystem at Risk (PIER). 2021. Institute of Pacific Islands Forestry. http://www.hear.org/pier/species/ panicum_repens.htm

Prince, C. M., and G. E. MacDonald. 2020. "Chemical Control of Torpedograss and Common Reed under Altered Salinity Conditions." J. Aquat. Plant Manage. 58:26-35.

Ramiti, A., N. Liphschitz, and Y. Waisel. 1979. "Osmotic Adaptation in Panicum repens: Differences between Organ, Cellular and Subcellular Levels." Physiol. Plant 45:325-331. https://doi.org/10.1111/j.1399-3054.1979.tb02592.x

Schardt, J. D. 1994. "Florida Aquatic Plant Survey 1992.” Tech. Report 942-CGA. Florida Dept. of Environmental Protection, Tallahassee.

Tabor, P. 1952. "Comments on Cogon and Torpedograss: A Challenge to Weed Workers." Weeds 1:374-375. https://doi. org/10.2307/4040035

Tarver, D. P. 1979. “Torpedograss (Panicum repens L.).” Aquatics 1:5-6.

USDA, NRCS. 2021. The PLANTS Database. National Plant Data Team, Greensboro, NC 27401-4901 USA. https:// plants.usda.gov/home

Wilcut, J. W., B. Truelove, D. E. Davis, and J. C. Williams. 1988. "Temperature Factors Limiting the Spread of Cogongrass (Imperata cylindrica) and Torpedograss
(Panicum repens)." Weed Science 36 (1): 49-55. https://doi. org/10.1017/S0043174500074440 